\title{
Minireview
}

\section{Cultivation of Uncultured Chloroflexi Subphyla: Significance and Ecophysiology of Formerly Uncultured Chloroflexi 'Subphylum I' with Natural and Biotechnological Relevance}

\author{
TAKESHI YAMADA ${ }^{1}$, and YUJI SEKIGUCHI ${ }^{2 *}$ \\ ${ }^{1}$ Department of Ecological Engineering, Toyohashi University of Technology, 1-1 Hibarigaoka, Tempaku, Toyohashi \\ 441-8580, Japan; and ${ }^{2}$ Institute for Biological Resources and Functions, National Institute of Advanced Industrial \\ Science and Technology (AIST), 1-1-1 Higashi, Tsukuba 305-8566, Japan
}

(Received May 31, 2009—Accepted July 30, 2009—Published online August 20, 2009)

Cultivation-independent molecular surveys have shown members of the bacterial phylum Chloroflexi to be ubiquitous in various natural and artificial ecosystems. Among the subphylum-level taxa of the Chloroflexi known to date, the formerly uncultured 'subphylum I' had well been recognized as a typical group that contains a number of environmental gene clones with no culture representatives. In order to reveal their ecophysiology, attempts were made over the past decade to domesticate them into laboratory cultures, and significant advances have been made in cultivating strains belonging to the group. The microorganisms characterized so far include seven species in six genera, i.e., Anaerolinea, Levilinea, Leptolinea, Bellilinea, Longilinea, and Caldilinea, and were proposed to represent two classes, Anaerolineae and Caldilineae, providing solid insights into the phenotypic and genetic properties common to the group. Another subphylum-level uncultured group of the Chloroflexi, i.e., the class Ktedonobacteria, has also been represented recently by a cultured strain. In addition to the results from these tangible cultures, data obtained from functional analyses of uncultured Chloroflexi populations by assessing substrate uptake patterns are accumulating at an encouraging rate. In this review, recent findings on the ecological significance and possible ecophysiological roles of 'Chloroflexi subphylum I' are discussed based on findings from both the characteristics of the cultured Chloroflexi and molecular-based analyses.

Key words: Chloroflexi, Anaerolineae, Caldilineae, uncultured microorganism

\section{Introduction}

Cultivation-independent molecular methods have provided new tools to study the microbial world, enabling us to understand the actual microbial diversity that traditional cultivation-based methods have never unveiled (32). With the application of these techniques, it has become evident that the majority of microorganisms in the environment are uncultured, and that the ecophysiology of these organisms remains largely unknown. The finding of yet-to-be cultured microorganisms have driven renewed efforts in the cultivation and isolation of such microbes, because the domestication (cultivation) of microorganisms into laboratory cultures is still the best means to gain solid insights into metabolic ability and detailed genomic traits of individual microbes. In the past few years, new microorganisms have been successfully isolated that belong to uncultured taxa with environmental and biotechnological relevance, and the information of their physiology in conjugation with phylogeny has been updated (63). Chloroflexi subphyla are also examples where

* Corresponding author. E-mail: y.sekiguchi@aist.go.jp; Tel: +8129-861-7866; Fax: +81-29-861-6400. such microbial groups have recently been cultured and characterized.

The phylum Chloroflexi, formerly known as 'Green nonsulfur bacteria', has been recognized as a typical ubiquitous bacterial taxon containing a number of diverse environmental 16S rRNA gene clones with a limited number of cultured representatives $(33,63)$. Formerly, the phylum had been divided into four major subphylum (class)-level taxa on the basis of $16 \mathrm{~S}$ rRNA/rRNA gene sequences, i.e. 'subphyla I, II, III, and IV (Fig. 1) (33), but the class Thermomicrobia has been reclassified into the phylum as an additional subphylum (34). The phylogenetic depth of the phylum is comparable with that of the phylum Proteobacteria (20). In addition to the major five subphyla, other uncultured lineages at the subphylum level were also identified $(14,63)$. Among the subphyla, 'subphylum III', known as the class Chloroflexi, has been best represented by cultured organisms belonging to the genera Chloroflexus, Oscillochloris, Chloronema, Heliothrix, Herpetosiphon, and Roseiflexus. These organisms mostly possess filamentous morphotypes, and show photoheterotrophic and/or chemolithoheterotrophic growth under mesophilic or moderately thermophilic conditions. The class Thermomicrobia also involves cultured organisms belonging 


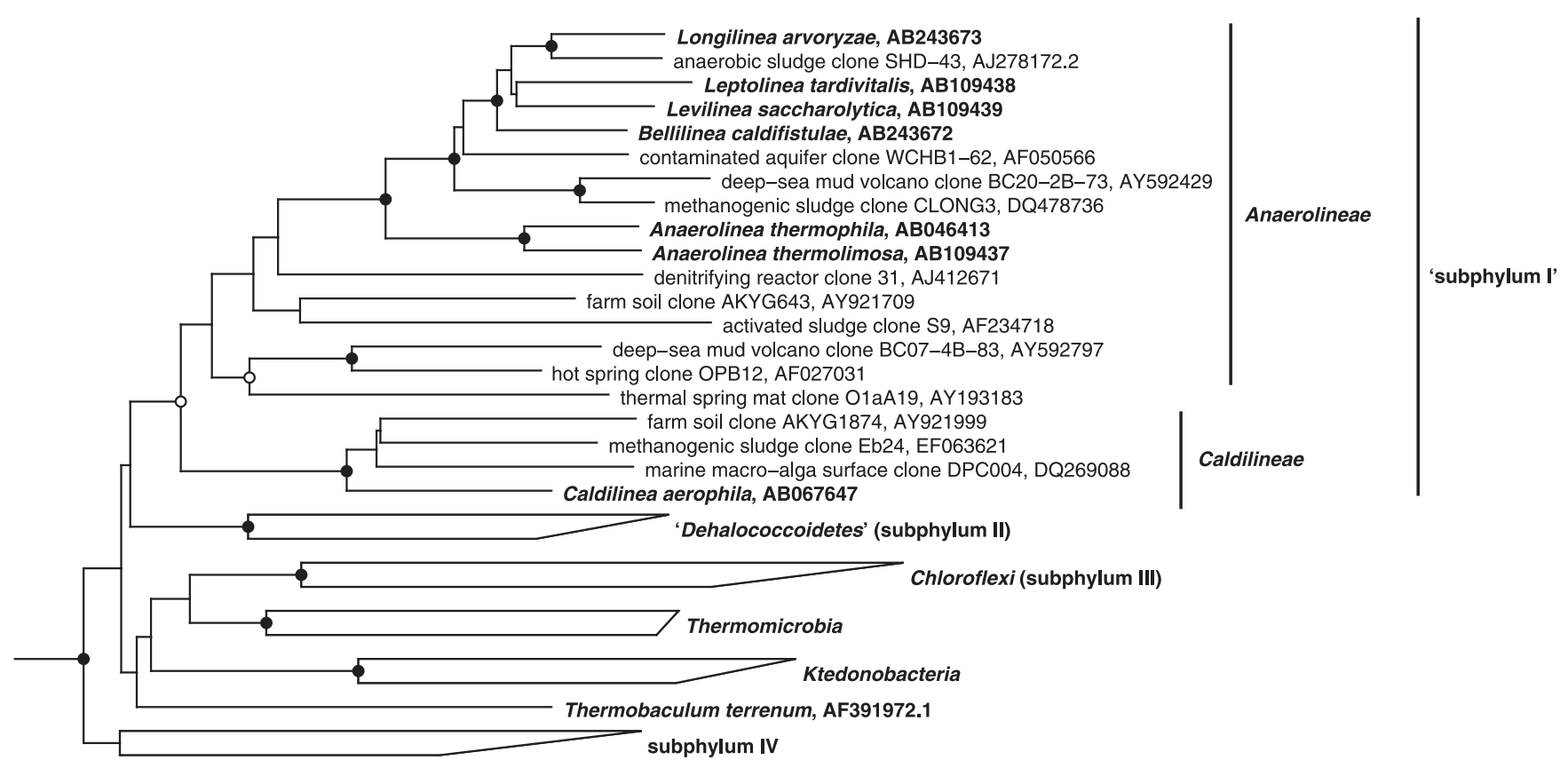

0.10

Fig. 1. Evolutionary distance dendrogram of the bacterial phylum Chloroflexi derived from a comparative analyses of $16 \mathrm{~S}$ rRNA gene sequences, showing the phylogenetic relationship of the subphyla (class)-level taxa of the phylum. The sequences were aligned, and the phylogenetic tree was constructed by the neighbor-joining (NJ) method with the ARB software package (52). The fidelity of the topology of the NJ tree was also confirmed by bootstrap resampling (based on 1,000 replicates) with the neighbor-joining (PAUP* 4.0 program package) and maximum likelihood (TREEFINDER program package) methods. Nodes highly supported with bootstrap values higher than $85 \%$ by both analyses are marked as circles (filled circles, $>95 \%$; open circles, $95-85 \%$ ). Nodes without symbols were not highly resolved $(<85 \%)$ as specific groups in either analysis. The bar represents 10 nucleotide substitutions per 100 nucleotides.

to the genera Thermomicrobium and Sphaerobacter (34), which are rod-shaped, moderately thermophilic or hyperthermophilic, chemoheterotrophic aerobes. In addition, Themobaculum terrenum, a moderately thermophilic chemolithoheterotrophic aerobe, represents a distinct lineage in the phylum, forming a new class-level taxon (9). The other three major subphyla (I, II, and IV) had been comprised solely of a variety of environmental clones except for purified, coccoidshaped organisms, 'Dehalococcoides ethenogenes' and related strains (e.g., $(1,53))$ able to reductively dechlorinate chlorinated compounds, being classified into 'subphylum II' (class 'Dehalococcoidetes') $(31,33)$. 'Subphylum I' contains the most diverse environmental clones among the four subphyla of the Chloroflexi; in the current 16S rRNA Ribosome Database Project (RDP) database (release 10.11), 'subphylum I' phylotypes are most frequently represented among the subphyla known to date and make up approximately $>70 \%$ ( $>5,000$ entries) of all the deposited sequences relative to the Chloroflexi phylum. Although the past two decades have seen a number of papers reporting the detection of 'Chloroflexi subphylum I' in various ecosystems (see below), there had long been no description of cultivable microbes. However, in recent years, aerobic and anaerobic strains have successfully been cultivated and characterized that belong to 'subphylum I'. The microorganisms characterized so far are seven species in six genera in total, and were proposed to represent two distinct classes Anaerolineae and Caldilineae. In addition, an aerobic strain has recently been isolated and characterized that belongs to another uncultured lineage at the subphylum level in the Chloroflexi phylum, representing a new class, Ktedonobacteria.

In this review, recent findings on the ecological significance and possible ecophysiological roles of the formerly uncultured Chloroflexi subphyla are discussed based on findings from rRNA-based community analyses for the environment, as well as from the characteristics of recently cultured Chloroflexi. In addition, recent studies on the ecophysiology of these organisms in engineered systems through the evaluation of their substrate uptake pattern are described. Special emphasis is placed on the ecology and function of Chloroflexi 'subphylum I' members with natural and biotechnological relevance, particularly those found in waste/ wastewater treatment systems.

\section{Ecological significance of Chloroflexi subphyla}

In 1998, Hugenholtz et al. analyzed 16S rRNA gene sequences of 5,224 cultured bacteria and 2,918 environmental gene clones retrieved from a wide range of natural and artificial ecosystems, revealing ubiquitous bacterial groups to be those of the phyla Proteobacteria, Actinobacteria, Firmicutes, Bacteroidetes, Planctomycetes, Acidobacteria, Verrucomicrobia, and Chloroflexi, and the candidate phylum OP11 (33). In the past decade, a flood of papers reporting the molecular detection of Chloroflexi phylotypes in a variety of environments have been published, further supporting their 
Table 1. Relative abundance of Chloroflexi phylotypes in natural and artificial ecosystems as determined by $16 \mathrm{~S}$ rRNA gene-based clone library analyses

\begin{tabular}{|c|c|c|c|c|c|c|c|c|c|c|c|c|c|c|c|c|}
\hline \multirow{3}{*}{ Subphyla } & \multicolumn{11}{|c|}{ Natural habitats } & \multicolumn{5}{|c|}{ Artificial habitats } \\
\hline & \multicolumn{4}{|c|}{ Sediment } & \multicolumn{3}{|c|}{ Soil } & \multirow{2}{*}{$\begin{array}{l}\text { Hot } \\
\text { spring }\end{array}$} & \multirow[b]{2}{*}{ Freshwater } & \multirow[b]{2}{*}{ Ocean } & \multirow{2}{*}{$\begin{array}{l}\text { Hypersaline } \\
\text { lake }\end{array}$} & \multicolumn{2}{|c|}{ Wastewater treatment } & \multirow[b]{2}{*}{ Lagoon } & \multirow{2}{*}{$\begin{array}{l}\text { Mine } \\
\text { drainage }\end{array}$} & \multirow{2}{*}{$\begin{array}{l}\text { Microbial } \\
\text { fuel cell } \\
\text { system }\end{array}$} \\
\hline & $\begin{array}{l}\text { Deep } \\
\text { seafloor }\end{array}$ & Sea & Lake & River & Agricultural & Geothermal & Meadow & & & & & Aerobic & Anaerobic & & & \\
\hline $\begin{array}{l}\text { Subphylum I } \\
\text { (Anaerolineae and } \\
\text { Caldilineae) }\end{array}$ & $\mathrm{O}^{\mathrm{a}}$ & 0 & 0 & 0.00 & 000 & 0 & 0 & 0.0 & 0 & - & 0.000 & 0 & 0.000 & 0 & 0 & 0.00 \\
\hline $\begin{array}{l}\text { Subphylum II } \\
\text { ('Dehalococcoidetes') }\end{array}$ & 0 & - & - & 00 & - & - & - & - & - & - & - & - & - & - & - & - \\
\hline $\begin{array}{l}\text { Subphylum III } \\
\text { (Chloroflexi) }\end{array}$ & - & - & - & - & - & - & - & 0.0 & - & - & 0.000 & 0 & - & - & 0 & - \\
\hline Subphylum IV & 0.000 & - & - & - & - & - & - & - & 0 & 0 & - & - & - & - & - & - \\
\hline New subphyla & 0 & - & - & 0 & - & - & 0 & - & - & - & - & - & - & - & - & - \\
\hline References & 59 & 54 & 82 & 46 & 5 & 78 & 22 & 48 & 85,99 & 29 & 50 & $\begin{array}{l}42,45, \\
56\end{array}$ & $\begin{array}{c}3,24,58 \\
64,90\end{array}$ & 97 & 79 & 39,64 \\
\hline
\end{tabular}

${ }^{a}$ Frequency of clones assigned to a subphylum of Chloroflexi as a percentage of the total number of bacterial sequencs analyzed: - $0 \% ; \bigcirc, 0.1-5 \% ; 0,5-15 \%, \bigcirc 0,15-25 \%, 0 \bigcirc,>25 \%$.

ubiquity in natural and engineered environments (Table 1). For example, Chloroflexi phylotypes were found as the most numerous bacterial group (nearly $80 \%$ of all bacterial gene clones analyzed) in an organic-rich deep subseafloor biosphere (38), where these phylotypes mainly fall into 'subphyla I, II and IV'. Similarly, Chloroflexi are often one of the most dominating bacterial phyla in various deep subseafloor sediments (e.g., (7), see also a recent review by Fry et al. (27)), some of which were associated with methane hydratebearing sites $(38,59)$. Other natural environments where Chloroflexi phylotypes were detected in abundance are hot springs (e.g., $(4,48))$, hypersaline microbial mats (e.g., $(50))$, soil (e.g., agricultural soils $(5,75)$, geothermal soils $(78)$, and low-temperature meadow soils (14)), sediment (e.g., sea and lake (river) sediment $(18,35,46,54,82,89)$, and hydrothermally active sediment $(79,83))$, chlorinated-solvent-contaminated aquifer sites $(21,26,88))$, oceans $(e . g .,(6,29,63$, 87)), and freshwater (e.g., $(85,99))$.

Recently, Lau et al. analyzed the bacterial communities of microbial mats from five hot springs (temperature: 60$65^{\circ} \mathrm{C}$ ), indicating that $10-15 \%$ of the phylotypes detected were related with the Chloroflexi phylum (48). These Chloroflexi phylotypes fall into 'subphyla I and III'. Similarly, Chloroflexi phylotypes were found in a hypersaline (salinity: 8\%) microbial mat as the majority of the mat constituents $(21-39 \%$ of the bacterial rRNA clones analyzed were those of the Chloroflexi phylum) (50). These Chloroflexi phylotypes, again, fall into the 'subphyla I and III'. In this study, quantitative rRNA-targeted dot blot hybridization was conducted with an oligonucleotide probe specific for the phylum Chloroflexi (GNSB941 probe, Fig. 2, Table 2), estimating their abundance to be $22-41 \%$ of the total rRNA. These microbial mats were fueled by sunlight, and therefore photosynthetic bacteria of the class Chloroflexi ('subphylum III') were found in association with uncultured 'subphylum I' organisms. Costello et al. determined the bacterial community of a tundra wet meadow soil, where the annual soil temperature was $0.3^{\circ} \mathrm{C}$ and the temperature was stable throughout the year, revealing Chloroflexi phylotypes to make up $16 \%$ of the bacterial rRNA gene clones (14). In this case, the phylotypes found were classified into 'subphylum I' as well as other formerly and currently uncultured, previously unrecognized groups at the subphylum level, including the class Ktedonobacteria (see below). These findings suggest a wide range of temperature $\left(0\right.$ to $\left.65^{\circ} \mathrm{C}\right)$ and salinity for the habitats of Chloroflexi.

Soil is believed to be one of the most complex environments for microbial life (15). Concerning Chloroflexi phylotypes in soil environments, a recent review by Janssen showed the Chloroflexi to be one of the most dominant phyla in soils: 32 previously published clone libraries for different soil samples were re-evaluated and the mean contribution of the Chloroflexi phylum to soil bacterial communities was found to be 3\% (range: 0-16\%) (40). Similarly, pyrosequencing of rRNA gene clone libraries ( $c a$. 150,000 clones in total) for different soils further supported the significance and genetic diversity of the Chloroflexi population $(22,65)$. Concerning the Chloroflexi phylum in oceanic and freshwater bacterioplanktons, environmental clones belonging to 'subphylum IV' (formerly known as cluster SAR202) were found in the Sargasso sea (4\% of bacterial clones) (29), and similar phylotypes were detected in different ocean samples (6). Freshwater bacterioplankton also often contain the Chloroflexi phylum (average: $1 \%$, range: $0-4 \%$ ), most of them affiliated with 'subphyla I and IV' $(85,99)$.

Chloroflexi phylotypes have also been found in abundance in artificial and engineered ecosystems, such as lagoons (e.g., (97)), mine drainage (e.g., $(73,79))$, anaerobic sludges for waste and wastewater treatment (e.g., $(2,12,17,19,25,30$, $43,51,57,58,64,66,71,74,76,90,94))$, activated sludge systems (e.g., $(3,8,13,25,42,45,47,55,56,60,62,77,80$, $98)$ ), and microbial fuel cell systems $(39,61)$. Among these ecosystems, waste/wastewater treatment facilities are perhaps the best-recognized habitat where Chloroflexi phylotypes reside in abundance. For example, Rivière et al. evaluated bacterial and archaeal community structures of seven mesophilic $\left(29-37^{\circ} \mathrm{C}\right)$, anaerobic (methanogenic) digesters decomposing municipal sewage sludge and found the Chloroflexi to be the most abundant bacterial phylum (average: $32 \%$ of all the bacterial clones analyzed, range: $15-45 \%$ ) 


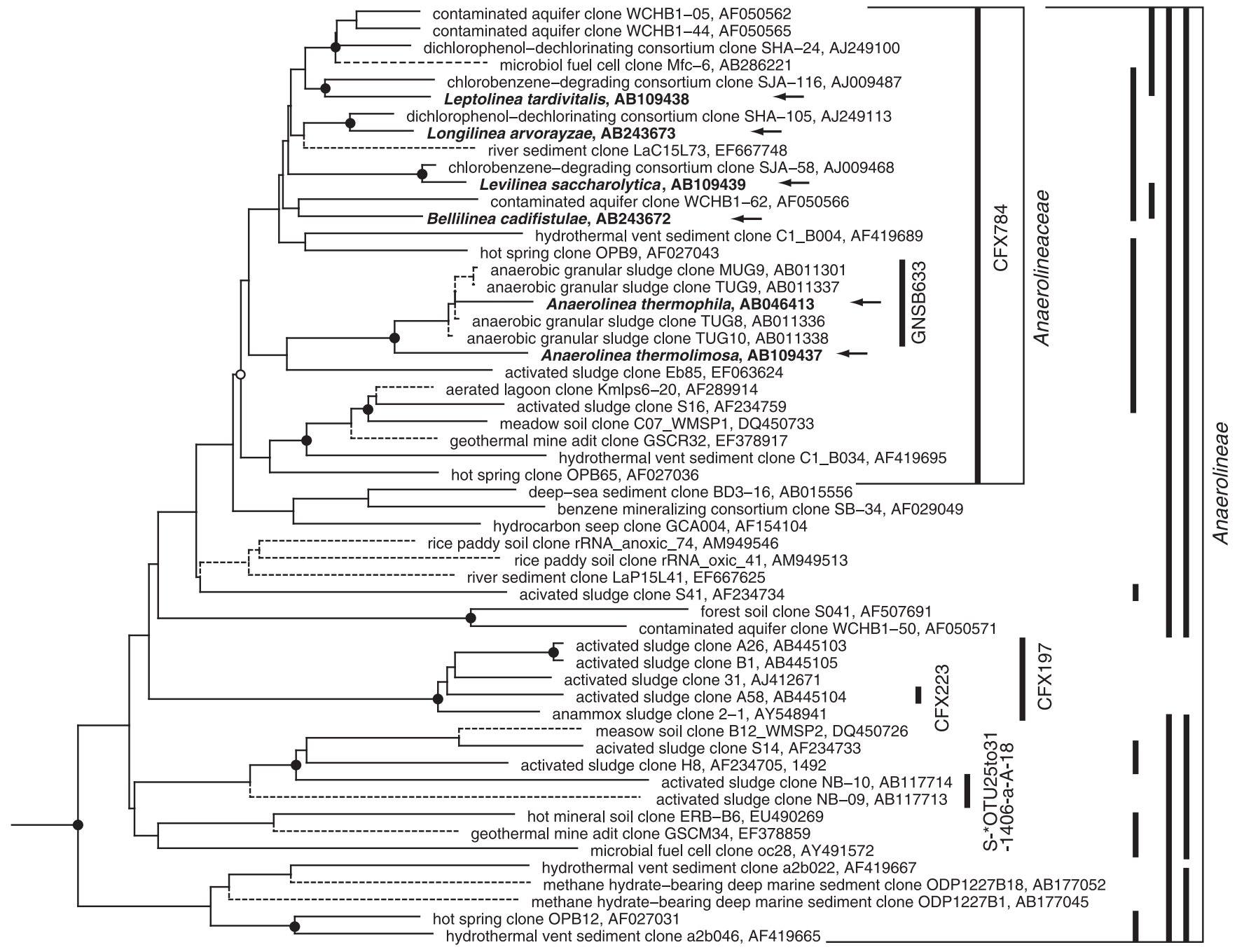

0.10

Fig. 2. Evolutionary distance dendrogram of the class Anaerolineae derived from a comparative analyses of $16 \mathrm{~S}$ rRNA gene sequences, showing the phylogenetic positions of cultivated strains belonging to the class (indicated by arrow) and other related gene clones that were retrieved from a variety of environments. The sequences were aligned, and the phylogenetic tree was constructed by the NJ method with the ARB software package (52). The base tree was constructed with $>1,200 \mathrm{nt}$ sequences. Partial sequences of $<1,200 \mathrm{nt}$ (highlighted with dotted branches) were inserted into the base tree using the parsimony insertion tool of the ARB program. 16S rRNA gene sequences of members affiliated with the phylum Thermotogae were used as outgroups (not shown in the tree). The bar represents 10 nucleotide substitutions per 100 nucleotides. The fidelity of the topology of the $\mathrm{NJ}$ tree was also confirmed by bootstrap resampling (based on 1,000 replicates) with the neighbor-joining (PAUP* 4.0 program package) and maximum likelihood (TREEFINDER program package) methods. Nodes highly supported with bootstrap values higher than $85 \%$ by both analyses are marked as circles (filled circles, $>95 \%$; open circles, $95-85 \%$ ). Nodes without symbols were not highly resolved $(<85 \%)$ as specific groups in either analysis. Probe specificity is shown to the right of the figure with the probe name; the bars indicate a perfect match between the probe and target sequences.

(64). All the Chloroflexi phylotypes detected were affiliated with 'subphylum I'. Chouari et al. conducted quantitative rRNA-targeted dot blot hybridization with an oligonucleotide probe specific to the phylum Chloroflexi (GNSB1126 probe, Fig. 2, Table 2) for a mesophilic $\left(33^{\circ} \mathrm{C}\right)$, anaerobic digester for sewage sludge, estimating their abundance to be
$20 \%$ of the total rRNA (12). Similarly, Narihiro et al. estimated the microbial diversity of twelve different types of mesophilic $\left(35-40^{\circ} \mathrm{C}\right)$, anaerobic (methanogenic) sludges treating organic wastewaters, detecting Chloroflexi phylotypes as a predominant phylum (average: $12 \%$ of the bacterial clones analyzed, range: $0-32 \%$ ) (58). The abundance of 
Table 2. 16S rRNA-tageting oligonucleotide probes used for in situ detection of the Chloroflexi phylum and 'subphylum I'

\begin{tabular}{|c|c|c|c|c|c|}
\hline Oligonucleotide & Target group & Probe sequences $\left(5^{\prime}-3^{\prime}\right)$ & $\begin{array}{c}\text { Target site } \\
\text { (E. coli position) }\end{array}$ & $\begin{array}{l}\text { Length } \\
\text { (nt) }\end{array}$ & References \\
\hline GNSB941 & $\begin{array}{l}\text { virtually all members of the phylum } \\
\text { Chloroflexi }\end{array}$ & AAACCACACGCTCCGCT & $941-957$ & 17 & 28 \\
\hline CFX1223 & $\begin{array}{l}\text { virtually all members of the phylum } \\
\text { Chloroflexi }\end{array}$ & CCATTGTAGCGTGTGTGTMG & $1223-1242$ & 20 & 8 \\
\hline GNSB1126 & members of the class Anaerolineae & AACACACAGCGAGGG & $1112-1126$ & 15 & 12 \\
\hline CFX784 & members of the class Anaerolineae & ACCGGGGTCTCTAATCCC & $784-801$ & 18 & 8 \\
\hline GNSB633 & Anaerolinea thermophila & TAGCCCGCCAGTCTTGAACG & $633-652$ & 18 & 68 \\
\hline S-*OTU25to31-1406-a-A-18 & $\begin{array}{l}\text { uncultured phylotypes of the class } \\
\text { Anaerolineae }\end{array}$ & CCAGCTCCCATGACGTGA & $1406-1423$ & 18 & 42 \\
\hline S-*GNS-0667-a-A18 & $\begin{array}{l}\text { uncultured phylotypes of the class } \\
\text { Anaerolineae }\end{array}$ & CACCCSGAATTCCACRTT & $667-684$ & 18 & 45 \\
\hline CFX197 & $\begin{array}{l}\text { uncultured phylotypes of the class } \\
\text { Anaerolineae }\end{array}$ & TCCCGGAGCGCCTGAACT & $197-214$ & 18 & 80 \\
\hline CFX223 & $\begin{array}{l}\text { uncultured phylotypes of the class } \\
\text { Anaerolineae }\end{array}$ & GGTGCTGGCTCCTCCCAG & $223-240$ & 18 & 80 \\
\hline
\end{tabular}

Groups targeted by the probes are shown in Fig. 2.

these phylotypes varied depending on wastewater type, and all of them fell into 'subphylum I'. Similar phylotypes ('subphylum I') have been frequently found in anaerobic sludges that had treated wastewaters containing compounds recalcitrant to biodegradation, such as phenol $(11 \%$ of bacterial clones) (24), phthalates $(4-7 \%,(51,90))$, 4-methylbenzoate, $(7 \%,(90)), 2,4$-dinitroanisole and n-methyl-4-nitroaniline $(36-42 \%,(3))$.

Chloroflexi phylotypes are often present in activated sludge systems; phylogenetic analysis of activated sludge clones belonging to the Chloroflexi phylum indicated that they are affiliated with 'subphyla I and III' $(8,47)$. These clones were most abundant in submerged membrane bioreactors treating municipal wastewater (Chloroflexi phylum-specific probes, GNSB941 and CFX1223, were used for in situ detection and the probe-reactive cells accounted for $14-26 \%$ of the total, (56)). The phylotypes found in the systems again fall into 'subphyla I and III'. Nitrifying systems were also shown to contain these Chloroflexi in abundance; Kindaichi et al. found that phylotypes belonging to 'subphylum I' were dominant (13\% of bacterial clones analyzed) in nitrifying biofilms formed in a submerged rotating disk reactor (45). Chloroflexi cells were found in abundance in nitrifyingdenitrifying systems, in which uncultured 'subphylum I' cells (as detected using the probe S-*OTU25to31-1406-a-A-18, Fig. 2) accounted for $16 \%$ of the cells (42). Another example of these engineered ecosystems is the microbial fuel cell. The microbial fuel cell is a bio-electrochemical system that generates electric power from organic matter, in which Chloroflexi phylotypes are often found. For example, a phylotype affiliated with 'subphylum I' was one of the most dominant ( $17 \%$ of bacterial clones) in a microbial fuel cell system fed with cellulose (39).

These molecular inventories of Chloroflexi phylotypes in a wide range of natural and human-made ecosystems strongly suggest the ecological significance and physiological breadth of these organisms, playing indispensable roles in such habitats.

\section{Cultivation of uncultured Chloroflexi at the subphylum level}

The classes Anaerolineae and Caldilineae as 'Chloroflexi subphylum I'. Phylotypes affiliated with 'subphylum I' are detected in a wide range of environments, and the group now contains the most diverse rRNA gene sequences among known subphyla with strong natural and biotechnological relevance. To unveil their physiology, attempts were made to cultivate them, and the first pure culture representing the group, i.e., Anaerolinea thermophila, was obtained in 2001 from a thermophilic $\left(55^{\circ} \mathrm{C}\right)$ anaerobic sludge treating organic wastewater $(71,72)$. Simultaneously, the second tangible organism of the group, Caldilinea aerophila, was obtained from a hot spring (72). Later, a new thermophilic species of the genus Anaerolinea and four species of four genera, i.e., Levilinea, Leptolinea, Bellilinea, and Longilinea, were successfully cultivated and characterized $(92,93)$. To our knowledge, these seven species are only the cultivated organisms of 'subphylum I'.

The morphology, physiology, and genetic properties of cultivated strains of the two classes are shown in Table 3. The strains are anaerobic or aerobic, mesophilic or moderately thermophilic, multicellular filamentous, chemolithoorganoheterotrophic organisms degrading carbohydrates and amino acids (or peptides). No growth was found in the dissimilatory reduction of nitrate and sulfate. It may not be appropriate to conclude that 'subphylum I' is comprised solely of such heterotrophs, but based on the unveiled physiological traits of these microorganisms, common features that make 'subphylum I' recalcitrant to isolation are likely to be (1) a relatively slow growth rate compared to commonly cultivable microbes and/or (2) the need to associate with other microbes (syntrophy) for efficient growth. In fact, the Anaerolinea-type anaerobes cultivated so far are all very slow growers (doubling time: 45-92 hrs), and hence are easily outcompeted by fast-growing heterotrophic anaerobes like Clostridia- and Thermoanaerobacter-type cells. We actually found that irrelevant fast-growing microbes immediately outcompeted Anaerolinea-type cells when we 
Table 3. Characteristics of cultivated species belonging to classes Anaerolineae and Caldilineae in the phylum Chloroflexi

\begin{tabular}{|c|c|c|c|c|c|c|c|}
\hline \multirow{2}{*}{ Characteristic } & \multicolumn{6}{|c|}{ Class Anaerolineae } & \multirow{2}{*}{$\begin{array}{c}\text { Class } \\
\text { Caldilineae } \\
\begin{array}{c}\text { Caldilinea } \\
\text { aerophila }\end{array}\end{array}$} \\
\hline & $\begin{array}{l}\text { Anaerolinea } \\
\text { thermophila }\end{array}$ & $\begin{array}{l}\text { Anaerolinea } \\
\text { thermolimosa }\end{array}$ & $\begin{array}{c}\text { Levilinea } \\
\text { saccarolytica }\end{array}$ & $\begin{array}{l}\text { Leptolinea } \\
\text { tardivitalis }\end{array}$ & $\begin{array}{l}\text { Bellilinea } \\
\text { caldifistulae }\end{array}$ & $\begin{array}{l}\text { Longilinea } \\
\text { arvoryzae }\end{array}$ & \\
\hline Type strain & strain UNI-1 ${ }^{\mathrm{T}}$ & strain IMO- $1^{\mathrm{T}}$ & strain KIBI- $1^{\mathrm{T}}$ & strain YMTK-2 $2^{\mathrm{T}}$ & strain GOMI- $1^{\mathrm{T}}$ & strain KOME- $1^{\mathrm{T}}$ & strain STL-6-O1 ${ }^{\mathrm{T}}$ \\
\hline Cell diameter $(\mu \mathrm{m})$ & $0.2-0.3$ & $0.3-0.4$ & $0.4-0.5$ & $0.15-0.2$ & $0.2-0.4$ & $0.4-0.6$ & $0.7-0.8$ \\
\hline Temperature range $\left({ }^{\circ} \mathrm{C}\right)$ & $50-60$ & $42-55$ & $25-50$ & $25-50$ & $45-65$ & $30-40$ & $37-65$ \\
\hline $\begin{array}{l}\text { Optimum growth } \\
\text { temperature }\left({ }^{\circ} \mathrm{C}\right)\end{array}$ & 55 & 50 & $37-40$ & 37 & 55 & 37 & 55 \\
\hline $\mathrm{pH}$ range & $6.0-8.0$ & $6.5-7.5$ & $6.0-7.2$ & $6.0-7.2$ & $6.0-8.5$ & $5.0-7.5$ & $7.0-9.0$ \\
\hline Optimum growth $\mathrm{pH}$ & around 7.0 & around 7.0 & around 7.0 & around 7.0 & around 7.0 & around 7.0 & around $7.5-8.0$ \\
\hline Doubling time $(\mathrm{h})$ & $72(48)^{*}$ & $48(10)^{*}$ & $56(56)^{*}$ & $50(50)^{*}$ & $45(29)^{*}$ & $92(38)^{*}$ & 5 (N.D)* \\
\hline $\mathrm{O}_{2}$ respiration & - & - & - & - & - & - & + \\
\hline Major cellular fatty acids & $\begin{array}{l}\mathrm{C}_{16: 0}, \mathrm{C}_{15: 0} \\
\mathrm{C}_{14: 0}\end{array}$ & $\begin{array}{c}\text { ai- } C_{17: 0}, \mathrm{i}-\mathrm{C}_{15: 0}, \\
\mathrm{C}_{16: 0}\end{array}$ & $\begin{array}{c}\mathrm{C}_{14: 0}, \mathrm{i}-\mathrm{C}_{15: 0} \\
\mathrm{C}_{16: 0}\end{array}$ & $\begin{array}{l}\text { Branched } C_{17: 0}, \\
\mathrm{C}_{16: 0}, \mathrm{C}_{14: 0}\end{array}$ & $\begin{array}{l}\mathrm{C}_{16: 0}, \mathrm{C}_{14: 0} \\
\quad \mathrm{i}-\mathrm{C}_{15: 0}\end{array}$ & $\begin{array}{c}\mathrm{i}-\mathrm{C}_{15: 0}, \mathrm{ai}-\mathrm{C}_{15: 0} \\
\mathrm{C}_{14: 0}\end{array}$ & $\begin{array}{l}\mathrm{C}_{18: 0}, \mathrm{C}_{16: 0} \\
\mathrm{C}_{17: 0}\end{array}$ \\
\hline Major quinone & - & - & - & - & - & - & MK-10 \\
\hline DNA G+C content $(\mathrm{mol} \%)$ & 54.5 & 53.3 & 59.5 & 48.2 & 54.7 & 54.5 & 59.0 \\
\hline \multicolumn{8}{|l|}{$\begin{array}{l}\text { Utilization in the presence } \\
\text { of yeast extract of: }\end{array}$} \\
\hline Tryptone & \pm & + & + & + & \pm & + & + \\
\hline Betain & ND & - & \pm & + & - & - & ND \\
\hline Pyruvate & \pm & + & + & \pm & + & - & + \\
\hline Glucose & + & + & + & + & + & - & + \\
\hline Mannose & + & + & \pm & + & + & - & - \\
\hline Galactose & + & + & \pm & \pm & + & - & ND \\
\hline Fructose & + & + & + & + & + & \pm & - \\
\hline Arabinose & \pm & + & - & \pm & + & - & - \\
\hline Xylose & \pm & + & + & + & \pm & - & - \\
\hline Ribose & \pm & + & + & + & + & - & - \\
\hline Pectin & \pm & \pm & \pm & + & + & + & ND \\
\hline Starch & + & \pm & - & \pm & - & - & + \\
\hline Isolation source & $\begin{array}{l}\text { Thermophilic } \\
\text { UASB sludge }\end{array}$ & $\begin{array}{l}\text { Thermophilic } \\
\text { UASB sludge }\end{array}$ & $\begin{array}{l}\text { Mesophilic } \\
\text { UASB sludge }\end{array}$ & $\begin{array}{l}\text { Mesophilic } \\
\text { UASB sludge }\end{array}$ & $\begin{array}{l}\text { Thermophilic } \\
\text { anaerobic sludge }\end{array}$ & $\begin{array}{l}\text { Rice paddy } \\
\text { soil }\end{array}$ & Hot spring \\
\hline Reference & 71,72 & 93,94 & 93,94 & 93,94 & 92 & 92 & 72 \\
\hline
\end{tabular}

* Doubling time in parentheses indicates that for sytrophic growth with hydrogenotrophic methanogens.

-, Negative; \pm , variable; +, positive; ND, not determined. Only differences found among the strains are listed. All strains showed the following characteristics: multicellular filamentous morphology; growth under anaerobic conditions (fermentation).

attempted to isolate them $(70,71)$. This is probably the primary reason why many attempts to isolate 'subphylum I' organisms have failed. Consequently, selecting appropriate inocula, in which 'subphylum I'-type cells are highly abundant, is one of the keys to success (71). In fact, the cultivation and isolation of Anaerolinea thermophila was possible only when we used spine-like structures of sludge granules as the inoculum, in which Anaerolinea cells were highly concentrated. In the isolation, highly enriched portions of Anaerolinea cells were found by fluorescence in situ hybridization (FISH) with the probe GNSB633 (Fig. 2, Table 2), and were carefully washed and serially diluted in liquid medium. In this case, the fast-growing anaerobes outgrew the Anaerolinea cells in lower dilutions, but the Anaerolinea grew slowly in the highest dilution, in which growth was also checked as determined by FISH with GNSB633. Such rRNA-directed cultivation may be also important for cultivating uncultured cells. In fact, four strains of the genera Anaerolinea, Levilinea and Leptolinea were successfully isolated by this approach, with rRNA-directed cultivation using inocula that contain 'subphylum I' cells in abundance (71, 94).
Another approach that eliminates irrelevant fast-growing heterotrophic microbes (i.e., 'subphylum I' cells) is to establish primary enrichment cultures that allow the growth of other slow growing bacteria, such as syntrophic propionateoxidizers (37). When we constructed methanogenic, syntrophic propionate-degrading enrichment cultures, we found that they contained GNSB941 probe-positive filamentous cells as a concomitant population (92). Therefore, the enrichment cultures were transferred to anaerobic media that support the growth of Anaerolinea-type cells, resulting in the cultivation and isolation of two additional anaerobes of the genera Bellilinea and Longilinea (92). In primary enrichment cultures, they might survive on certain remnants from the propionate-oxidizing community. Similarly, Caldilinea aerophila was isolated from a primary aerobic enrichment culture to focus on the isolation of chemolithotrophic thermophiles (72). For the primary enrichment culture, thiosulfate was used as the sole energy source, and the cultured cells were subsequently transferred to an aerobic organic medium, resulting in the cultivation and isolation of C. aerophila. Similar to Bellilinea and Longilinea, C. aerophila survived on remnants from the community that formed during the 


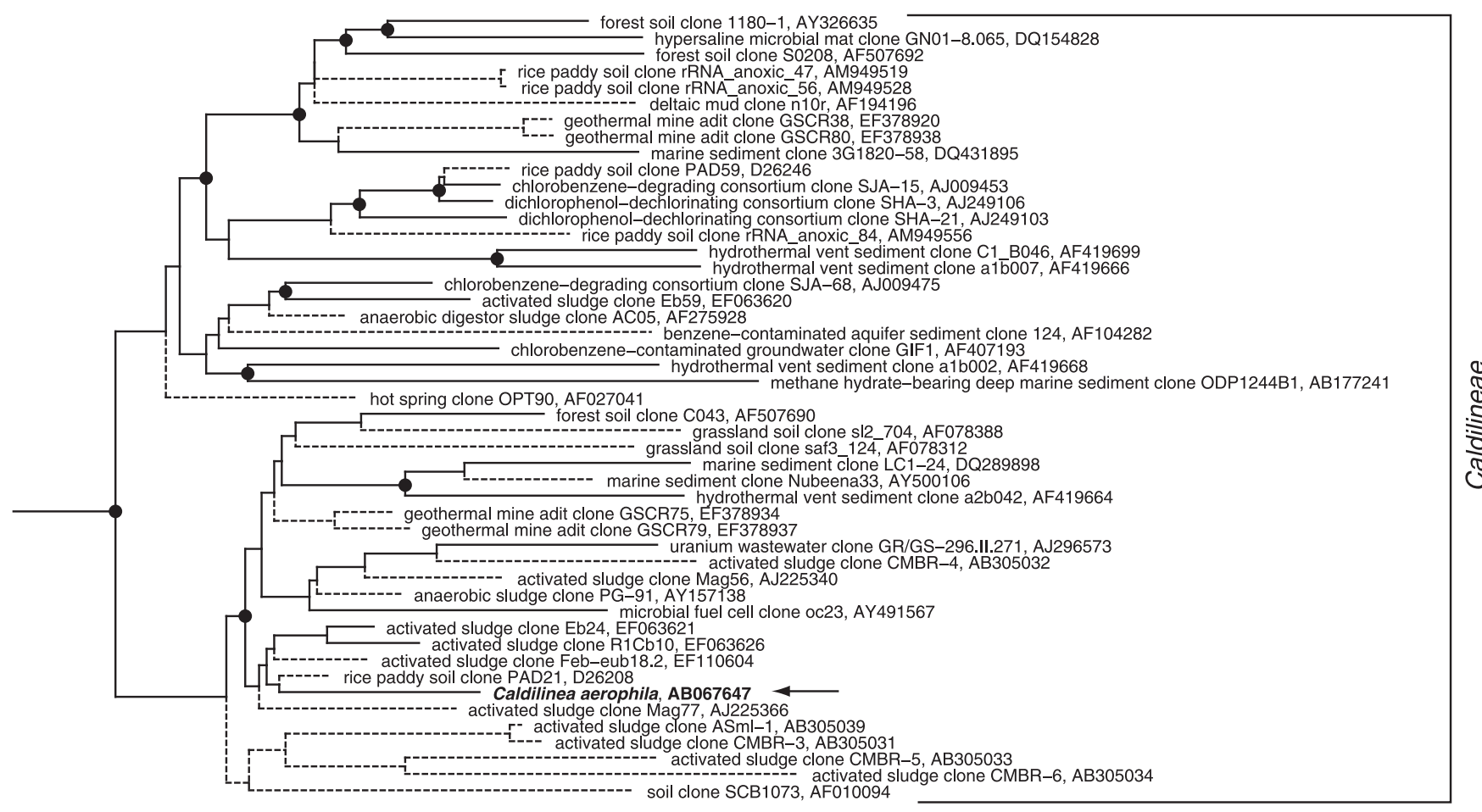

0.05

Fig. 3. Evolutionary distance dendrogram of the class Caldilineae derived from a comparative analysis of $16 \mathrm{~S}$ rRNA gene sequences, showing the phylogenetic positions of Caldilinea aerophila (indicated by arrow) and other related gene clones that were retrieved from a variety of environments. The tree was constructed and marked as described in the legend of Fig. 2. The bar represents 5 nucleotide substitutions per 100 nucleotides.

primary enrichment, because $C$. aerophila cannot utilize thiosulfate as an energy source. In contrast, inoculating the original sample (hot spring microbial mat) directly into the same aerobic, organic medium resulted in the cultivation of typical fast growers like Thermus-type cells (72). These cases also demonstrated that the elimination of fast-growers from an inoculum is indispensable to the cultivation of 'subphylum I'.

Co-cultivation is an additional strategy. In the enrichment of Anaerolinea-type anaerobes, hydrogenotrophic methanogens were added beforehand, which stimulated the growth of 'subphylum I' anaerobes (94). Interestingly, some 'subphylum I' anaerobes produced hydrogen as an end product of fermentation, and grew more rapidly when co-cultivated with hydrogenotrophic methanogens (Table 3), indicating that they are "semi-syntrophic" bacteria requiring a hydrogen-scavenging partner for efficient growth $(71,72,92,93)$. Because microorganisms rarely live in pure cultures, this approach may be generally applicable to uncultured strains, whereby in situ conditions are appropriately mimicked, using co-cultivation for example.

These results indicated that it is still feasible to apply traditional cultivation techniques to the isolation of unseen microbes, if they are used thoughtfully in combination with molecular tools, and with carefully selected inocula, which contain sufficient amounts of targeted cells. By using a combination of these approaches, more novel microbes belonging to 'subphylum I' may be obtained.

Concerning the higher taxonomy of these organisms, the monophyly of 'subphylum I' was evaluated in detail based on the 16S rRNA gene sequences of these cultured organisms and environmental gene sequences, and the group was found not to be a monophyletic taxon (93), as suggested by Hugenholtz and Stackebrandt (34). In particular, the Caldilinea cluster did not often form a clade with other members of Anaerolineae (93). Thus, it was concluded that 'subphylum I' should be phylogenetically subdivided into at least two class-level taxa (Fig. 1), the class Anaerolineae representing the majority of lineages in 'subphylum I' (Fig. 2) and the class Caldilineae representing a deeply branched lineage relative to the Anaerolineae (Fig. 3). Physiologically, distinct differences, such as aerobic respiration, were found in the cultured members of the two classes (Table 3). Whole-genome analyses of $A$. thermophila and C. aerophila are now underway to unveil detailed genetic properties of these organisms (http://www.bio.nite.go.jp/ngac/e/projecte.html), which may also help to further assess the evolutional relationship among the Chloroflexi subphyla.

Other cultured subphyla of the Chloroflexi phylum. Recently, a novel strain was isolated from a soil and named Ktedobacter racemifer (11). The bacterium is a Gram-positive, aerobic, chemolithoorganoheterotrophic organism that produces branched vegetative mycelia, growing well under microaerobic conditions; this finding further expanded the morphological diversity of the phylum. Phylogenetically, the bacterium represents a new subphylum-level clade of the Chloroflexi phylum, to which the name Ktedonobacteria classis nov. has been given $(11,23)$. The subphylum (class)level clade contains a variety of environmental gene clones (>100 sequences in public databases) retrieved mainly from 
soil samples (these sequences can be browsed on the recent version of the greengene database (http://greengenes.lbl.gov/).

In addition to the class Ktedonobacteria, Davis et al. successfully isolated a strain belonging to a formerly uncultured Chloroflexi clade at the subphylum level, called the Ellin7237 lineage, from a soil sample using nontraditional aerobic media solidified with gellan (16). The lineage contains a relatively small number of environmental gene sequences mainly from soil environments (these sequences can also be seen on the greengene database (http://greengenes.lbl.gov/). Although detailed physiological properties of the strain have not yet been published, the bacterium will also provide new information on the genetic and phenotypic traits of the newly cultured subphylum. Gellan-based methods were found to be more effective than conventional agarbased techniques for culturing uncultured strains (10, 41, $44)$, resulting in the isolation of novel bacterial lineages, even at the phylum level, using media solidified with gellan $(16,81)$. This approach may also be useful for further isolating and characterizing uncultured Chloroflexi phylotypes.

\section{Ecophysiology and function of the Chloroflexi 'subphylum I'}

Members of the class Anaerolineae in anaerobic sludge. The cultured Anaerolineae (the cultured members of the genera Anaerolinea, Levilinea, Leptolinea, Bellilinea, and Longilinea) share common physiological and morphological traits, such as anaerobic (fermentative) growth on carbohydrates and/or peptides (amino acids) and a multicellular filamentous morphology. Considering that the class Anaerolineae contains a number of rRNA gene clone sequences mainly retrieved from anoxic environments, most of which were obtained from anaerobic (methanogenic) sludges $(2,12$, $30,51,57,58,64,66,71,74,90,94)$, the common physiological traits of the cultured Anaerolineae are likely to represent those of organisms in the Anaerolineae, at least those of the Anaerolineaceae lineage (Fig. 2). For example, a layered microbial structure of different trophic groups of anaerobes was often found within granular sludges in upflow anaerobic sludge blanket (UASB) systems treating organic wastewaters (e.g., $(36,70))$, with the Anaerolineae-type populations often found in the outer most layer of such sludge granules $(66,70$, $71,94)$. This unique architecture of sludge granules is considered to be a result of substrate profiles formed within the granules (68). That is, because the methanogenic conversion of organic matter is driven by a food web of different trophic groups of anaerobes, i.e., fermentative heterotrophs, protonreducing syntrophic bacteria, and methanogenic archaea (68), fermentative heterotrophs, that mainly utilize primary substances in wastewaters such as carbohydrates, mainly reside in the outer layer of granules. That Anaerolineae populations were found in the outer layers of sludge granules suggests them to be heterotrophic degraders, decomposing carbohydrates, for example. In addition, because yeast extract and peptides are good substrates for cultured Anaerolineae (Table 3), and some Anaerolineaceae-type filaments were also found inside of sludge granules (94), they may be able to act as degraders of cellular materials (like amino acids) that are present inside sludge granules.
Based on FISH using oligonucleotide probes for Chloroflexi members (Fig. 2 and Table 2), the Anaerolineae in anaerobic sludge were shown to be filamentous. For example, FISH using a probe (GNSB 633) specific for Anaerolinea thermophila showed that all of the probereactive cells in thermophilic sludges had a thin-filamentous morphotype $(70,71)$. FISH experiments using GNSB633 or a Chloroflexi-specific probe (GNSB941) for various types of anaerobic sludge also indicated that the probe-reactive cells were all filamentous with a wide range of thicknesses $(66,70$, $71,94)$. Considering that almost all the Chloroflexi-related $16 \mathrm{~S}$ rRNA gene sequences in anaerobic sludges are classified into the class Anaerolineae, the filamentous morphology observed with the GNSB941 probe may be a common trait of the Anaerolineae lineage.

Interestingly, this filamentous morphotype was found to be important for biotechnological reasons: Anaerolineae members are considered important for the granulation of sludge in UASB reactors, as well as the formation of fluffy sludge (bulking) in similar treatment systems. The granulation of sludge (formation of sludge granules with good settleability) is the major premise for the start-up and stable operation of UASB reactors $(67,69)$. It was reported that the granulation of thermophilic sludges was difficult to achieve when volatile fatty-acid mixtures were used as the sole substrate, while the addition of sucrose or glucose to the influent wastewater resulted in the formation of a granular sludge with good settleability $(84,86)$. In thermophilic UASB reactors having well-settleable sludge granules, Anaerolineatype filamentous microbes predominated on the surface of the granules $(70,71,94)$. Considering these findings together with the physiological properties of the cultured Anaerolineae, Anaerolinea-type filaments are indispensable organisms to the granulation of thermophilic UASB sludges, forming a web-like coating on the surface of granules $(70,71,94)$.

Besides their importance in thermophilic UASB reactors, Anaerolinea-type organisms microorganism are a potential causative agent for the bulking of granular sludges (71). Once these filaments outgrew in the system, the sludge became fluffy, resulting in flotation and washout of the sludge from the system $(71,95)$. Similar observations were made in mesophilic anaerobic systems $(71,91,95,96)$. Therefore it is important to control the growth of these filamentous Anaerolineae not only to enhance the formation of granules but also to prevent the bulking of sludge granules.

Members of the class Anaerolineae in activated sludge systems. Although Anaerolineae strains have not yet been cultivated and isolated from oxic environments, phylotypes of the class have been frequently found in oxic systems like activated sludges (Fig. 2). FISH for the detection of Anaerolineae-type cells in activated sludges revealed that all of the probe-reactive cells were filamentous $(8,45,55,56,60,80)$. For example, Björnsson et al. used a probe (CFX784) specific for part of the class Anaerolineae and a probe (CFX109) for the class Chloroflexi ('subphylum III') for in situ detection of these organisms in various activated sludge systems and found that Anaerolineae in sludge samples were generally thin $(<1 \mu \mathrm{m})$, smooth filaments, although they were less abundant than filamentous Chloroflexi ('subphylum III') 
cells as detected with CFX109 (8).

To reveal the ecophysiology of these Anaerolineae-type organisms in activated sludge systems, functional analyses were conducted using microautoradiography-fluorescent in situ hybridization (MAR-FISH) (45, 49). For example, using the MAR-FISH method, substrate uptake patterns of uncultured Chloroflexi, particularly those of the class Anaerolineae, were studied for autotrophic nitrifying biofilms and revealed that the microbes aerobically utilized N-acetyl glucosamine, a major structural component of bacterial cells, as well as amino acids, implying that they metabolize cellular materials in the biofilms $(45,60)$. Similarly, Miura et $a l$. $(55,56)$ found using MAR-FISH that filamentous cells of the class Anaerolineae in membrane bioreactors (MBR) were metabolically versatile and preferentially utilized $\mathrm{N}$-acetyl glucosamine and glucose under oxic and anoxic conditions. Zang et al. observed that Anaerolineae-related cells incorporated decayed tritium-labeled bacterial cells in activated sludges (98). Based on these observations, it may be concluded that Anaerolineae-type organisms in activated sludge systems are likely to utilize carbohydrates, as well as to scavenge cellular materials formed in the systems, similar to the cultured Anaerolineae in anaerobic sludges.

The Chloroflexi filaments in activated sludge may provide a stabilizing backbone for sludge flocs, explaining one important role of these organisms in the systems (8). Miura et al. indicated that Anaerolineae-type filaments were responsible for the degradation of soluble microbial products, including carbohydrates and cellular materials from cells, consequently reducing membrane fouling potential in membrane bioreactors $(55,56)$. Anaerolineae-type filaments were also shown to be a causative agent for the filamentous bulking in activated sludge systems as well. Recently, Speirs et al. reported that Anaerolineae-type filamentous cells, as detected with the probes CFX197 and CFX223 (Table 2 and Fig. 2), are causative agents for aerobic filamentous bulking, which had long been recognized as Eikelboom Type 0092 (80). These studies demonstrate the importance of Anaerolinea organisms in activated sludge systems, drawing an analogy between their functions in oxic and anoxic (methanogenic) biological waste/wastewater treatment systems.

The class Caldilineae in natural and biotechnological systems. No detailed in situ studies have been conducted for the class Caldilinea, i.e., no specific oligonucleotide probes have been designed and no substrate-uptake properties have yet been elucidated. Although 16S rRNA gene sequences have been obtained from various ecosystems (Fig. 3), including hot springs (33), anaerobic sludges (76), aerobic sludges $(13,25,56)$, geothermal soil (79), marine sediment (35), hydrothermal vents (83), rice paddy soils (75) and chlorinated-solvent-contaminated aquifers (88), the ecophysiology and functions of this class remain to be clarified.

\section{Concluding remarks and perspectives}

In summary, recent cultivation and molecular-based studies suggest that microbes in the formerly uncultured Chloroflexi subphyla, Anaerolineae and Caldilineae in particular, may be filamentous, slowly growing, aerobic and anaerobic heterotrophs decomposing carbohydrates and amino acids, and often need to be associated with other microbes (syntrophy) for growth. They are ubiquitous in natural and artificial environments, and likely to play indispensable roles in ecosystems. They are often closely associated with the process performance of biological treatment systems, such as granule and floc formation and/or sludge bulking. Their ecophysiology and function have been well established based on information from cultured representatives, as well as from molecular-based ecological analyses, including an assessment of their substrate uptake patterns with the MARFISH technique. This synergism between traditional (or rRNAdirected) cultivation and molecular ecological analyses may be a promising strategy for further elucidating the function of these yet-to-be cultured lineages.

The cultivated Anaerolineae only make up part (the family Anaerolineaceae in Fig. 2) of the Anaerolineae lineage, and the class still contains surprisingly diverse, yet-to-be cultured environmental clades even at the subclass level (Fig. 2). The phylogenetic depth of the class is the highest among the Chloroflexi phylum (approximate rRNA gene sequence divergence of the class is $18 \%$ ), possibly suggesting the presence of more genetically (and phenotypically) diverse Anaerolineae organisms than the cultured Anaerolineae strains. Similarly, the recently cultured classes, Caldilineae and Ktedonobacteria, contain only single cultured strains. Other uncultured subphyla of the Chloroflexi phylum remain to be characterized (63). To further unveil the function of these lineages that are less represented by cultured organisms, rRNA-directed cultivation and molecular ecological analyses may be useful, and should be applied to environments where targeted populations are abundant. To efficiently isolate and cultivate these organisms, it may be necessary to employ newly developed cultivation approaches for yet-to-be cultured microbes (10). More comprehensive studies of these Chloroflexi subphyla, involving cultivation, molecular ecological analyses, (meta-) genomics, and transcriptomics, will allow us to gain deeper insight into their functions, which may answer questions such as why these organisms are so abundant and ubiquitous in the environment.

\section{References}

1. Adrian, L., U. Szewzyk, J. Wecke, and H. Görisch. 2000. Bacterial dehalorespiration with chlorinated benzenes. Nature 408:580-583.

2. Ariesyady, H.D., T. Ito, and S. Okabe. 2007. Functional bacterial and archaeal community structures of majar trophic groups in a full-scale anaerobic sludge digester. Water Res. 41:1554-1568.

3. Arnett, C.M., G. Rodriguez, and S.W. Maloney. 2009. Analysis of bacterial community diversity in anaerobic fluidized bed bioreactors treating 2,4-dinitroanisole (DNAN) and n-methyl-4-nitroaniline (MNA) using 16S rRNA gene clone libraries. Microbes Environ. 24:72-75.

4. Bachar, A., E. Omoregie, R.D. Wit, and H.M. Jonkers. 2007. Diversity and function Chloroflexus-like bacteria in a hypersaline microbial mat: Phylogenetic characterization and impact on aerobic respiration. Appl. Environ. Microbiol. 73:3975-3983.

5. Baertsch, C., T. Paez-Rubio, E. Viau, and J. Peccia. 2007. Source tracking aerosols released from land-applied class $\mathrm{B}$ biosolids during high-wind events. Appl. Environ. Microbiol. 73:4522-4531.

6. Bano, N., and J.T. Hollibaugh. 2002. Phylogenetic composition of bacterioplankton assemblages from the Arctic Ocean. Appl. Environ. Microbiol. 68:505-518. 
7. Biddle, J.F., S. Fitz-Gibbon, S.C. Schuster, J.E. Brenchley, and C.H. House. 2008. Metagenomic signatures of the Peru Margin subseafloor biosphere show a genetically distinct environment. Proc. Natl. Acad. Sci. USA 105:10583-10588.

8. Björnsson, L., P. Hugenholtz, G.W. Tyson, and L.L. Blackall. 2002. Filamentous Chloroflexi (green non-sulfur bacteria) are abundant in wastewater treatment processes with biological nutrient removal. Microbiology 148:2309-2318.

9. Botero, L.M., K.B. Brown, S. Brumefield, M. Burr, R.W. Castenholz, M. Young, and T.R. McDermott. 2004. Thermobaculum terrenum gen. nov., sp nov.: A non-phototrophic gram-positive thermophile representing an environmental clone group related to the Chloroflexi (green non-sulfur bacteria) and Thermomicrobia. Arch. Microbiol. 181:269-277.

10. Cardenas, E., and J.M. Tiedje. 2008. New tools for discovering and characterizing microbial diversity. Curr. Opin. Biotechnol. 19:544 549.

11. Cavaletti, L., P. Monciardini, R. Bamonte, P. Schumann, M. Rohde, M. Sosio, and S. Donadio. 2006. New lineage of filamentous, sporeforming, gram-positive bacteria from soil. Appl. Environ. Microbiol. 72:4360-4369.

12. Chouari, R., D.L. Paslier, P. Daegelen, P. Ginestet, J. Weissenbach, and A. Sghir. 2005. Novel predominant archaeal and bacterial groups revealed by molecular analysis of an anaerobic sludge digester. Environ. Microbiol. 7:1104-1115.

13. Christensson, M., L.L. Blackall, and T. Welander. 1998. Metabolic transformations and characterization of the sludge community in an enhanced biological phosphorus removal system. Appl. Microbiol. Biotechnol. 49:226-234.

14. Costello, E.K., and S.K. Schmidt. 2006. Microbial diversity in alpine tundra wet meadow soil: Novel Chloroflexi from a cold, watersaturated environment. Environ. Microbiol. 8:1471-1486.

15. Curtis, T.P., W.T. Sloan, and J.W. Scannell. 2002. Estimating prokaryotic diversity and its limits. Proc. Natl. Acad. Sci. USA 99:10494-10499.

16. Davis, K.E.R., S.J. Joseph, and P.H. Janssen. 2005. Effects of growth medium, inoculum size, and incubation time on culturability and isolatiion of soil bacteria. Appl. Environ. Microbiol. 71:826-834.

17. Delbès, C., R. Moletta, and J.-J. Godon. 2008. Monitoring of activity dynamics of an anaerobic digester bacterial community using 16S rRNA polymerase chain reaction-single-strand conformation polymorphism analysis. Environ. Microbiol. 2:506-515.

18. Dhillon, A., A. Taske, J. Dillon, D.A. Stahl, and M.L. Sogin. 2003. Molecular characterization of sulfate-reducing bacteria in the Guaymas Basin. Appl. Environ. Microbiol. 69:2765-2772.

19. Diaz, E.E., A.J.A. Stams, R. Amils, and J.L. Sanz. 2006. Phenotypic properties and microbial diversity of methanogenic granules from a full-scale upflow anaerobic sludge bed reactor treating brewery wastewater. Appl. Environ. Microbiol. 72:4942-4949.

20. Dojka, M.A., J.K. Harris, and N.R. Pace. 2000. Expanding the known diversity and environmental distribution of an uncultured phylogenetic division of bacteria. Appl. Environ. Microbiol. 66:16171621.

21. Dojka, M.A., P.H. Hungenholtz, S.K. Haack, and N.R. Pace. 1998. Microbial diversity in a hydrocarbon- and chlorinated-solventcontaminated aquifer undergoing intrinsic bioremediation. Appl. Environ. Microbiol. 64:3869-3877.

22. Elshahed, M.S., N.H. Youssef, A.M. Spain, and et al. 2008. Novelty and uniqueness patterns of rare members of the soil biosphere. Appl. Environ. Microbiol. 74:5422-5428.

23. Euzéby, J. 2007. List of new names and new combinations previously effectively, but not validly, published. Int. J. Syst. Evol. Microbiol. $57: 433-434$.

24. Fang, H.H.P., D.W. Liang, T. Zhang, and Y. Liu. 2006. Anaerobic treatment of phenol in wastewater under thermophilic condition. Water Res. 40:427-434.

25. Fernández, N., R.S.-Alvarez, J.A. Field, R. Amils, and J.L. Sanz. 2008. Microbial community dynamics in a chemolithotrophic dinitrification reactor inoculated with methanogenic granular sludge. Chemosphere 70:462-474.

26. Ficker, M., K. Krastel, S. Orlicky, and E. Edwards. 1999. Molecular characterization of a toluene-degrading mathanogenic consorium. Appl. Environ. Microbiol. 65:5576-5585.

27. Fry, J.C., R.J. Parkes, B.A. Cragg, A.J. Weightman, and G. Webster.
2008. Prokaryotic biodiversity and activity in the deep subseafloor biosphere. FEMS Microbiol. Ecol. 66:181-196.

28. Gich, F., J. Garcia-Gil, and J. Overmann. 2001. Previously unknown and phylogenetically diverse members of the green nonsulfur bacteria are indigeneous to freshwater lakes. Arch. Microbiol. 177:1-10.

29. Giovannoni, S.J., M.S. Rappe, K.L. Vergin, and N.L. Adair. 1996. 16S rRNA genes reveal stratified open ocean bacterioplankton populations related to the Green Non-Sulfur bacteria. Proc. Natl. Acad. Sci. USA 93:7979-7984.

30. Godon, J.-J., E. Zumsten, P. Dabert, F. Habouzit, and R. Moletta. 1997. Molecular microbiol diversity of an anaerobic digestor as determined by small-subunit rDNA sequence analysis. Appl. Environ. Microbiol. 63:2802-2813.

31. Hiraishi, A. 2008. Biodiversity of dehalorespiring bacteria with special emphasis on polychlorinated biphenyl/dioxin dechlorinators. Microbes Environ. 23:1-12.

32. Hugenholtz, P. 2002. Exploring prokaryotic diversity in the genomic era. Genome Biol. 3:reviews0003.1-reviews0003.8.

33. Hugenholtz, P., B.M. Goebel, and N.R. Pace. 1998. Impact of cultureindependent studies on the emerging phylogenetic view of bacterial diversity. J. Bacteriol. 180:4765-4774.

34. Hugenholtz, P., and E. Stackebrandt. 2004. Reclassification of Sphaerobacter thermophilus from the subclass Sphaerobacteridae in the phylum Actinobacteria to the class Thermomicrobia (emended description) in the phylum Chloroflexi (emended description). Int. J. Syst. Evol. Microbiol. 54:2049-2051.

35. Hunter, E.M., H.J. Mills, and J.E. Kostka. 2006. Microbial community diversity associated with carbon and nitrogen cycling in permeable shelf sediments. Appl. Environ. Microbiol. 72:5689-5701.

36. Iguchi, A., T. Terada, T. Narihiro, T. Yamaguchi, Y. Kamagata, and Y. Sekiguchi. 2009. In situ detection and quantification of uncultured members of the phylum Nitrospirae abundant in methanogenic wastewater treatement systems. Microbes Environ. 24:97-104.

37. Imachi, H., Y. Sekiguchi, Y. Kamagata, A. Ohashi, and H. Harada 2000. Cultivation and in situ detection of a thermophilic bacterium capable of oxidizing propionate in syntrophic association with hydrogenotrophic methanogens in a thermophilic methanogenic granular sludge. Appl. Environ. Microbiol. 66:3608-3615.

38. Inagaki, F., T. Nunoura, S. Nakagawa, and et al. 2006. Biogeographical distribution and diversity of microbes in methane hydrate-bearing deep marine sediments on the Pacific Ocean Margin. Proc. Natl. Acad. Sci. USA 103:2815-2820.

39. Ishii, S., T. Shimoyama, Y. Hotta, and K. Watanabe. 2008. Characterization of a filamentous biofilm community established in a cellulosefed microbial fuel cell. BMC Microbiol. 8:6.

40. Janssen, P.H. 2006. Identifying the dominant soil bacterial taxa in libraries of $16 \mathrm{~S}$ rRNA and 16S rRNA genes. Appl. Environ. Microbiol. 72:1719-1728.

41. Janssen, P.H., P.S. Yates, B.E. Grinton, P.M. Taylor, and M. Sait. 2002. Improved culturability of soil bacteria and isolation in pure culture of novel members of the divisions Acidobacteria, Actinobacteria, Proteobacteria, and Verrucomicrobia. Appl. Environ. Microbiol. 68:2391-2396.

42. Juretschko, S., A. Loy, A. Lehner, and M. Wagner. 2002. The microbiol community composition of a nitrifying-denitrifying activated sludge from an industrial sewage treatment plant analyzed by the fullcycle rRNA approach. Syst. Appl. Microbiol. 25:84-89.

43. Kaksonen, A.H., J.J. Plumb, P.D. Franzmann, and J.A. Puhakka 2004. Simple organic electron donors support diverse sulfate-reducing communities in fludized-bed reactors treating acidic metal- and sufate-containning wastewater. FEMS Microbiol. Ecol. 47:279-289.

44. Kamagata, Y., and H. Tamaki. 2005. Cultivation of uncultured fastidious microbes. Microbes Environ. 20:85-91.

45. Kindaichi, T., T. Ito, and S. Okabe. 2004. Ecophysiological interaction between nitrifying bacteria and heterotrophic bacteria in autotrophic nitrifying biofilms as determined by microautoradiography-fluorescence in situ hybridization. Appl. Environ. Microbiol. 70:1641-1650.

46. Kittelmann, S., and M.W. Friedrich. 2008. Identification of novel perchloroethene-respiring microorganisms in anoxic river sediment by RNA-based stable isotope probing. Environ. Microbiol. 10:31-46.

47. Kragelund, C., C. Levantesi, A. Borger, and et al. 2007. Identity, abundance and ecophysiology of filamentous Chloroflexi species present in activated sludge treatment plants. FEMS Microbiol. Ecol. 
$59: 671-682$.

48. Lau, M.C.Y., J.C. Aitchison, and S.B. Pointing. 2009. Bacterial community composition in thermophilic microbial mats from five springs in central Tibet. Extremophiles 13:139-149.

49. Lee, N., P.H. Nielsen, K.H. Andreasen, S. Juretschko, J.L. Nielsen, K.-H. Schleifer, and M. Wagner. 1999. Combination of fluorescent in situ hybridization and microautoradiography - a new tool for structure-function analyses in microbial ecology. Appl. Environ. Microbiol. 65:1289-1297.

50. Ley, R.E., J.K. Harris, J. Wilcox, and et al. 2006. Unexpected diversity and complexity of the Guerrego Negro hypersaline microbial mat. Appl. Environ. Microbiol. 72:3685-3695.

51. Liang, D.-W., H.H.P. Fang, and T. Zhang. 2009. Microbial characterization and quantification of an anaerobic sludge degrading dimethyl phthalate. J. Appl. Microbiol. 106:296-305.

52. Ludwig, W., O. Strunk, R. Westram, and et al. 2004. ARB: A software environment for sequence data. Nucleic Acids Res. 32:13631371 .

53. May, H.D., G.S. Miller, B.V. Kjellerup, and K.R. Sowers. 2008. Dehalorespiration with polychlorinated biphenyls by an anaerobic ultramicrobacterium. Appl. Environ. Microbiol. 74:2089-2294.

54. Mills, H.J., E. Hunter, M. Humphrys, L. Kerkhof, L. McGuinness, M. Huettel, and J. Kostka. 2008. Characterization of nitrifying, denitrifying, and overall bacterial communities in permeable marine sediments of the northeastern gulf of mexico. Appl. Environ. Microbiol. 74:4440-4453.

55. Miura, Y., and S. Okabe. 2008. Quantification of cell specific uptake activity of microbial products by unclutured Chloroflexi by microautoradiography combined with fluorescence in situ hybridization. Environ. Sci. Technol. 42:7380-7386.

56. Miura, Y., Y. Watanabe, and S. Okabe. 2007. Significance of Chloroflexi in peformance of submerged membrane bioreactors (MBR) treating municipal wastewater. Environ. Sci. Technol. 41:7787-7794.

57. Narihiro, T., and Y. Sekiguchi. 2007. Microbial communities in anaerobic digestion processes for waste and wastewater treatment: a microbiological update. Curr. Opin. Biotechnol. 18:273-278.

58. Narihiro, T., T. Terada, K. Kikuchi, A. Iguchi, M. Ikeda, T. Yamauchi, K. Shiraishi, Y. Kamagata, K. Nakamura, and Y. Sekiguchi. 2009. Comparative analysis of bacterial and archaeal communities in methanogenic sludge granules from upflow anaerobic sludge blanket reactors treating various food-processing, highstrength organic wastwaters. Microbes Environ. 24:88-96.

59. Nunoura, T., F. Inagaki, M.E. Delwiche, F.S. Colwell, and K. Takai. 2008. Subseafloor microbial communities in methane hydrate-bearing sediment at two distinct locations (ODP Leg204) in the Cascadia margin. Microbes Environ. 23:317-325.

60. Okabe, S., T. Kindaichi, and T. Ito. 2005. Fate of ${ }^{14} \mathrm{C}$-labeled microbial products derived from nitrifying bacteria in autotrophic nitrifying biofilms. Appl. Environ. Microbiol. 71:3987-3994.

61. Phung, N.T., J. Lee, K.H. Kang, I.S. Chang, G.M. Gadd, and B.H. Kim. 2004. Analysis of microbial diversity in oligotrophic microbial fuel cells using 16S rDNA sequences. FEMS Microbiol. Lett. 233:77-82.

62. Qin, Y.-Y., D.-T. Li, and H. Yang. 2007. Investigation of total bacterial and ammonia-oxidizing bacterial community compostion in a full-scale aerated submerged biofilm reactor for drinking water pretreatment in China. FEMS Microbiol. Lett. 268:126-134.

63. Rappé, M.S., and S.J. Giovannoni. 2003. The uncultured microbial majority. Annu. Rev. Microbiol. 57:369-394.

64. Rivière, D., V. Desvignes, E. Pelletier, S. Chaussonnerie, S. Guermazi, J. Weissenbach, T. Li, P. Camacho, and A. Sghir. 2009. Towards the definition of a core of microorganisms involved in anaerobic digestion of sludge. ISME J. 3:700-714.

65. Roesch, L.F., R.R. Fulthorpe, A. Riva, and et al. 2007. Pyrosequencing enumerates and contrasts soil microbial diversity. ISME J. 1:283290

66. Satoh, H., Y. Miura, I. Tsushima, and S. Okabe. 2007. Layered structure of bacterial and archaeal communities and their in situ activities in anaerobic granules. Appl. Environ. Microbiol. 73:7300 7307.

67. Schmidt, J.E., and B.K. Ahring. 1996. Granular sludge formation in upflow anaerobic sludge blanket (UASB) reactors. Biotechnol. Bioeng. 49:229-246.
68. Sekiguchi, Y. 2006. Yet-to-be cultured microorganisms relevant to methane fermentation processes. Microbes Environ. 21:1-15.

69. Sekiguchi, Y., and Y. Kamagata. 2004. Microbial community structure and functions in methane fermentation technology for wastewater treatment, p.361-384. In M.M. Nakano, and P. Zuber (ed.), Strict and Facultative Anaerobes: Medical and Environmental Aspects. Horizon Bioscience, Wymondham, UK.

70. Sekiguchi, Y., Y. Kamagata, K. Nakamura, A. Ohashi, and H. Harada. 1999. Fluorescence in situ hybridization using 16S rRNAtargeted oligonucleotides reveals localization of methanogens and selected uncultured bacteria in mesophilic and thermophilic sludge granules. Appl. Environ. Microbiol. 65:1280-1288.

71. Sekiguchi, Y., H. Takahashi, Y. Kamagata, A. Ohashi, and H. Harada. 2001. In situ detection, isolation, physiological properties of a thin filamentous microorganism abundant in methanogenic granular sludges: a novel isolate affiliated with a clone cluster, the green nonsulfur bacteria, subdivision I. Appl. Environ. Microbiol. 67:57405749.

72. Sekiguchi, Y., T. Yamada, S. Hanada, A. Ohashi, H. Harada, and Y. Kamagata. 2003. Anaerolinea thermophila gen. nov., sp. nov. and Caldilinea aerophila gen. nov., sp. nov., novel filamentous thermophiles that represent a previously uncultured lineage of the domain Bacteria at the subphylum level. Int. J. Syst. Evol. Microbiol. 53:1843-1851.

73. Senko, J.M., P. Wanjugi, M. Lucas, M.A. Bruns, and W.D. Burgos 2008. Characterization of $\mathrm{Fe}(\mathrm{II})$ oxidizing bacterial activities and communities at two acidic Appalachian coalmine drainage-impacted sites. ISME J. 2:1134-1145.

74. Shigematsu, T., Y. Tang, H. Kawaguchi, K. Ninomiya, J. Kijima, T. Kobayashi, S. Morimura, and K. Kida. 2003. Effect of dilution rate on structure of a mesophilic acetate-degrading methanogenic community during continous cultivation. J. Biosci. Bioeng. 96:547-558.

75. Shrestha, P.M., M. Kube, R. Reinhardt, and W. Liesack. 2009. Transcriptional activity of paddy soil bacterial communities. Environ. Microbiol. 11:960-970.

76. Smith, N.R., Z. Yu, and W.W. Mohn. 2003. Stability of the bacterial community in a pulp mill effluent treatment system during normal operation and a system shutdown. Water Res. 37:4873-4884.

77. Snaider, J., R. Amann, I. Huber, W. Ludwig, and K.-H. Schleifer 1997. Phylogenetic analysis and in situ identification of bacteria in activated sludge. Appl. Environ. Microbiol. 63:2884-2896.

78. Soo, R.M., S.A. Wood, J.J. Grzymski, I.R. McDonald, and S.C. Cary. 2009. Microbial biodiversity of thermophilic communities in hot mineral soils of Tramway Ridge, Mount Erebus, Antarctica. Environ. Microbiol. 11:715-728.

79. Spear, J.R., H.A. Barton, C.E. Robertson, C.A. Francis, and N.R. Pace. 2007. Microbial community biofabrics in a geothermal mine adit. Appl. Environ. Microbiol. 73:6172-6180.

80. Speirs, L., T. Nittami, S. Mcllroy, S. Schroeder, and R.J. Seviour 2009. Filamentous bacterium Eikelboom Type 0092 in activated sludge plants in Australia is a member of the phylum Chloroflexi. Appl. Environ. Microbiol. 75:2446-2452.

81. Stott, M.B., M.A. Crowe, B.W. Mountain, A.V. Smirnova, S. Hou, M. Alam, and P.F. Dunfield. 2008. Isolation of novel bacteria, including a candidate division, from geothermal soils in New Zealand. Environ. Microbiol. 10:2030-2041.

82. Tamaki, H., Y. Sekiguchi, S. Hanada, K. Nakamura, N. Nomura, M. Matsumura, and Y. Kamagata. 2005. Comparative analysis of bacterial diversity in freshwater sediment of a shallow eutrophic lake by molecular and improved cultivation-based techniques. Appl. Environ. Microbiol. 71:2162-2169.

83. Teske, A., K.U. Hinrichs, V. Edgcomb, A. de Vera Gomez, D. Kysela, S.P. Sylva, M.L. Sogin, and H.W. Jannasch. 2002. Microbial diversity of hydrothermal sediments in the Guaymas Basin: Evidence for anaerobic methanotrophic communities. Appl. Environ. Microbiol. 68:1994-2007.

84. Uemura, S., and H. Harada. 1995. Inorganic composition and microbial characteristics of methanogenic granular sludge grown in a thermophilic upflow anaerobic sludge blanket reactor. Appl. Microbiol. Biotechnol 43:358-364.

85. Urbach, E., K.L. Vergin, L. Young, A. Morse, G.L. Larson, and S.J. Giovannoni. 2001. Unusual bacterioplankton community structure in ultra-oligotrophic Crater Lake. Limnol. Oceanogr. 46:557-572.

86. van Lier, J.B. 1996. Limitations of thermophilic anaerobic wastewater 
treatment and the consequences for process design. Antonie van Leeuwenhoek 69:1-14.

87. Venter, J.C., K. Remington, J.F. Heidelberg, and et al. 2004. Environmental genome shotgun sequencing of the Sargasso Sea. Science 304:66-74.

88. vonWintzingerode, F., B. Selent, W. Hegemann, and U.B. Göbel. 1999. Phylogenetic analysis of an anaerobic, trichlorobenzentransforming microbial consortium. Appl. Environ. Microbiol. 65:283-286.

89. Wise, M.G., J.V. Mcarthur, and L.J. Shimkets. 1997. Bacterial diversity of a carolina bay as determined by $16 \mathrm{~S}$ rRNA gene analysis: Cofirmination of novel taxa. Appl. Environ. Microbiol. 63:15051514.

90. Wu, J.-H., W.-T. Liu, I.-C. Tseng, and S.-S. Cheng. 2001. Characterization of microbial consortia in a terephthalate-degrading anaerobic granular sludge system. Microbiology 147:373-382.

91. Wu, W.-M., J.H. Thiele, M.K. Jain, H.S. Pankratz, R.F. Hickey, and J.G. Zeikus. 1993. Comparison of rod-versus filament-type methanogenic granules: microbial population and reactor performance. Appl. Microbiol. Biotechnol. 39:795-803.

92. Yamada, T., H. Imachi, A. Ohashi, H. Harada, S. Hanada, Y. Kamagata, and Y. Sekiguchi. 2007. Belllinea caldifistulae gen. nov., sp. nov. and Longilinea arvoryzae gen. nov., sp. nov., strictly anaerobic, filamentous bacteria of the phylum Chloroflexi isolated from methanogenic propionate-degrading consortia. Int. J. Syst. Evol. Microbiol. 57:2299-2306.

93. Yamada, T., Y. Sekiguchi, S. Hanada, H. Imachi, A. Ohashi, H. Harada, and Y. Kamagata. 2006. Anaerolinea thermolimosa sp. nov., Levilinea saccharolytica gen. nov., sp. nov. and Leptolinea tardivitalis gen. nov., sp. nov., novel filamentous anaerobes, and description of the new classes Anaerolineae classis nov. and Caldilineae classis nov. in the bacterial phylum Chloroflexi. Int. J. Syst. Evol. Microbiol. 56:1331-1340.

94. Yamada, T., Y. Sekiguchi, H. Imachi, Y. Kamagata, A. Ohashi, and H. Harada. 2005. Diversity, localization, and physiological properties of filamentous microbes belonging to Chloroflexi subphylum I in mesophilic and thermophilic methanogenic sludge granules. Appl. Environ. Microbiol. 71:7493-7503.

95. Yamada, T., T. Yamauchi, K. Shiraishi, P. Hugenholtz, A. Ohashi, H Harada, Y. Kamagata, K. Nakamura, and Y. Sekiguchi. 2007. Characterization of filamentous bacteria, belonging to candidate phylum $\mathrm{KSB} 3$, that are associated with bulking in methanogenic granular sludge. ISME J. 1:246-255.

96. Yoda, M., M. Kitagawa, and Y. Miyaji. 1989. Granular sludge formation in the anaerobic expanded microcarrier bed process. Water Sci. Technol. 21:165-173.

97. Yu, Z., and W.W. Mohn. 2001. Bacterial diversity and community structure in an aerated lagoon revealed by ribosomal intergenic spacer analysis and 16S ribosomal DNA sequencing. Appl. Environ. Microbiol. 67:1565-1574.

98. Zang, K., F. Kurisu, I. Kasuga, H. Furumai, and O. Yagi. 2008 Analysis of the phylogenetic diversity of estrone-degrading bacteria in activated sewage sludge using microautoradiography-fluorescence in situ hybridization. Syst. Appl. Microbiol. 31:206-214.

99. Zwart, G., B.C. Crump, M.P.K.V. Agterveld, F. Hagen, and S.K Han. 2002. Typical freshwater bacteria: An analysis of available 16S rRNA gene sequences from plankton of lakes and rivers. Aquat. Microb. Ecol. 28:141-155. 